\title{
Peningkatan Motivasi dan Penerimaan Keluarga dalam Merawat Pasien GGK dengan Terapi Hemodialisa melalui Supportive Educative Group Therapy
}

\author{
Dhina Widayati ${ }^{1}$, Nian Afrian Nuari $^{2}$, Joko Setyono ${ }^{3}$ \\ ${ }^{1,2,3}$ Program Studi Keperawatan, STIKES Karya Husada Kediri, Indonesia \\ Email: nian.afrian@yahoo.co.id
}

\begin{abstract}
Motivation and Family Acceptance in Caring for Chronic Renal Failure Patients With Hemodialysis By Supportive Educative Group Therapy. Patients with chronic renal failure (CRF) are terminal patients who require hemodialysis therapy to sustain life and improve their quality of life. Decrease in motivation and acceptance of the family will affect the patient, so that intervention is needed to increase motivation and family acceptance, one of which can be done through supportive educative group therapy. The purpose of this study was to determine the effect of supportive educative group therapy on motivation and family acceptance in caring for CRF patients with hemodialysis therapy. This research used Pre-Experimental design with one-group pre-post test design. Sample consists of 30 respondents picked up with Accidental sampling technique. Supportive Educative group therapy interventions for 45 minutes each session, consisting of 4 sessions and conducted in 2 meetings in 1 week. Before intervention supportive educative group therapy some respondents have motivation in the low category and acceptance in the category enough. After the intervention given the majority of respondents have motivation and acceptance in the high category. The data obtained in the analysis using the statistical test Wilcoxon sign rank test, with $\mathrm{p}$-value $=0.005$ (motivation) and $\mathrm{p}$-value $=0.001$ (family acceptance), $\alpha=0,05$ and $\mathrm{p}<\alpha$. The result of research showed there influence educative group therapy to motivation and family acceptance in treating patients with chronic renal failure who undergo hemodialysis therapy. Recommendations on the Hemodialisa RS unit can be able to apply supportive educative group therapy as a specialist therapy to provide comprehensive family nursing care and nursing services.
\end{abstract}

Keywords: CRF, Supportive educative group therapy, Motivation, Hemodialisa

\begin{abstract}
Abstrak: Peningkatan Motivasi dan Penerimaan Keluarga Dalam Merawat Pasien GGK Dengan Terapi Hemodialisa melalui Supportive Educative Group Therapy. Pasien gagal ginjal kronik (GGK) merupakan pasien terminal yang memerlukan penurunan motivasi dan penerimaan keluarga akan berdampak pada penderita, sehingga diperlukan intervensi untuk meningkatkan motivasi dan penerimaan keluarga yang salah satunya dapa dilakukan melalui supportive educative group therapy. Tujuan penelitian ini adalah untuk mengetahui pengaruh supportive educative group therapy terhadap motivasi dan penerimaan keluarga dalam merawat pasien GGK dengan terapi hemodialisa. Penelitian ini menggunakan desain Pre-Eksperimen dengan pendekatan penelitian one-group pre-post test design. Sampel terdiri dari 30 responden dengan teknik accidental sampling. Intervensi supportive educative group therapy selama 45 menit setiap sesinya, terdiri dari 4 sesi dan dilakukan dalam 2 kali pertemuan dalam 1 minggu.Sebelum dilakukan intervensi supportive educative group therapy sebagian responden memiliki motivasi dalam kategori rendah dan penerimaan dalam kategori cukup. Setelah diberikan intervensi mayoritas responden memiliki motivasi dan penerimaan dalam kategori tinggi. Data yang diperoleh di analisis menggunakan uji statistik Wilcoxon Sign rank test, dengan nilai $p$ value $=0,005$ (motivasi) dan $p$-value $=0,001$ (penerimaan keluarga), $\alpha=0,05$ dan $p<\alpha$. Hasil penelitian menunjukan ada pengaruh supportive educative group therapy terhadap motivasi dan penerimaan keluarga dalam merawat pasien gagal ginjal kronik yang menjalani terapi hemodialisa. Rekomendasi pada unit Hemodialisa dapat dapat menerapkan supportive educative group therapy sebagai terapi spesialistik guna memberikan asuhan keperawatan keluarga dan pelayanan keperawatan yang komprehensif.
\end{abstract}

Kata kunci: GGK, Hemodialisa, Motivasi, Supportive educative group therapy 
Gagal ginjal kronik (GGK) merupakan gangguan fungsi ginjal yang bersifat progesif dan irreversible, menyebabkan penurunan kemampuan ginjal untuk mempertahankan metabolisme dan keseimbangan cairan maupun elektrolit, sehingga timbul gejala uremia berupa retensi urea dan sampah nitrogen lain dalam darah (Smeltzer, 2008). Penyakit ginjal kronik adalah suatu proses patofisiologis dengan etiologi yang beragam, mengakibatkan penurunan fungsi ginjal yang progresif, dan pada umumnya berakhir dengan gagal ginjal. Ginjal yang tidak berfungsi dengan baik akan menyebabkan terjadinya penumpukan zat toksik (Nuari, NA \& Widayati, D, 2017). Penyakit ginjal kronik dapat berkembang secara cepat, dalam 2-3 bulan, ataupun secara lambat, dalam kurun waktu lebih dari 30-40 tahun. Penyakit ginjal kronik dapat menyebabkan berbagai komplikasi berat seperti penumpukan cairan di paru/ edema paru, anemia, hiperlipidemia, penyakit jantung, osteodistrofi renal, gangguan keseimbangan asam-basa, malnutrisi dan gangguan sistem saraf pusat. Komplikasikomplikasi tersebut terjadi pada fase gagal ginjal, dan memerlukan terapi pengganti ginjal dimana salah satunya adalah hemodialisis. Pasien yang menjalani hemodialisa jangka panjang harus dihadapkan dengan berbagai masalah seperti masalah finansial, kesulitan dalam mempertahankan pekerjaan, dorongan seksual yang hilang, depresi dan ketakutan terhadap kematian. Gaya hidup yang terencana berhubungan dengan terapi hemodialisa (misalnya pelaksanaan terapi hemodialisa 2-3 kali seminggu selama 3-4 jam) dan pembatasan asupan cairan sering menghilangkan semangat hidup atau motivasi pasien, ini menyebabkan pasien akan menghentikan proses terapi hemodialisa yang harus pasien lakukan secara rutin

Berdasarkan data Perhimpunan Nefrologi Indonesia, pada tahun 2008 jumlah pasien hemodialisa (cuci darah) mencapai 2.260 orang. Berdasarkan Hasil Riset Kesehatan Dasar (Riskesdas) tahun 2013 menunjukkan bahwa prevalensi penderita gagal ginjal kronik di Jawa Timur sebesar $0.3 \%$. dirumah sakit Bhayangkara Kediri jumlah pasien gagal ginjal kronik yang menjalani hemodialisa selalu bertambah dari tahun ke tahun. Jumlah penderita pada tahun 2015 mencapai 5724 pasien.

Klien GGK yang mengalami kelemahan fisik tidak mampu mengunjungi fasilitas kesehatan sendiri, sehingga diperlukan bantuan orang lain. Jarang sekali klien datang sendiri ke tempat pelayanan kesehatan tanpa pendamping atau dukungan dari keluarga dalam melakukan terapi. Klien dan keluarga memerlukan bantuan, penjelasan dan dukungan selama masa hemodialisa. Anggota keluarga mungkin takut untuk menyentuh dan mengajak bicara kepada klien selama prosedur dilakukan namun demikian mereka perlu didorong dan dibantu untuk melakukannya (Smeltzer, 2008). Hal tersebut menyebabkan klien mengalami ketergantungan yang terus-menerus sampai keluarga tersebut mampu memenuhi kebutuhan sehari-hari klien.

Beberapa penurunan fungsi tubuh yang dialami oleh penderita GGK dengan terapi hemodialisa dapat mengakibatkan klien merasa tidak mampu dan tidak berdaya karena keterbatasan fisiknya, sehingga klien menjadi malu/minder tidak mau bertemu dengan orang lain, tidak melakukan kegiatan sosial atau mengalami perubahan secara sosial. Perubahan spiritualnya klien merasa tidak mampu melakukan kegiatan keagamaan. Dampak dari perubahan yang terjadi pada klien akan mempengaruhi keluarga baik secara ekonomi, perhatian, kebosanan, merasakan beban yang berat dan menganggap hanya keluarga sendiri yang mempunyai permasalah yang sama. Dampak yang berlangsung lama akan menyebabkan konflik dalam keluarga. Konflik dalam keluarga tersebut dapat mengakibatkan stres keluarga dan dapat mengganggu struktur keluarga. Hal ini akan mempengaruhi motivasi dan penerimaan keluarga dalam merawat anggota keluarga yang sakit. Bila keluarga tidak mempunyai penerimaan yang baik maka justru dapat menurunkan motivasi keluarga tersebut. Tindakan manajemen stres dalam keluarga dapat menjadi alternatif solusi dalam menyelesaikan permasalahan-permasalahan yang berhubungan dengan beban keluarga dalam merawat anggota keluarga yang mengalami penyakit kronis.

Pemberian Terapi suportif educatif dalam setting group pada keluarga dengan klien GGK yang menjalani hemodialisa sangat diperlukan guna membantu keluarga untuk menyelesaikan masalah. Masalah dalam keluarga tersebut diantaranya beban ekonomi karena tindakan hemodialisa membutuhkan biaya yang tinggi dan rutin secara terus menerus. Beban secara psikologis yaitu keluarga harus mau mengantar anggota keluarga ke tempat pelayanan kesehatan dengan menunggu terapi hemodialisa dapat mengakibatkan kejenuhan. Waktu yang dibutuhkan antara 4-5 jam juga dapat digunakan oleh keluarga untuk hal yang lain. Dampak yang terjadi bila tidak diberikan terapi suportif edukatif pada keluarga adalah terganggunya struktur dan peran keluarga seperti terjadinya 
ketidakharmonisan, merasa diabaikan dan merasa tidak perlu diperhatikan serta tidak mampu memenuhi kebutuhan dalam keluarga. Pada klien juga akan mengalami beban psikologis yang berarti diantaranya klien merasa menjadi beban dalam keluarga.

Pemberian terapi suportif educatif akan memberikan keuntungan pada keluarga seperti keluarga dapat mengekpresikan masalah yang dihadapi, keluarga tidak merasa bahwa hanya sendirian saja yang mengalami beban, keluarga mendapatkan support system dari keluarga lain. Setiap anggota keluarga lain akan saling mendukung dan saling memahami permasalahan dalam keluarganya. Terapi suportif edukatif ini dilaksanakan dalam bentuk Supportive educative group therapy dengan terapi yang diorganisasikan untuk membantu keluarga bertukar pengalaman mengenai masalah masalah yang muncul selama anggota keluarga menjalani terapi hemodialisa agar dapat meningkatkan mekanisme koping dan motivasinya. Supportive educative group ditujukan untuk mengurangi beban Keluarga dan meningkatkan koping serta dukungan sosial. Maksud didirikannya supportive educative group adalah memberikan dukungan, fokus untuk pemulihan, aksi sosial termasuk kebijakan organisasi. Tujuan dan harapan dalam group adalah pengalaman kelompok yang positif. Tujuan penting adalah resolusi permasalahan dengan segera, memberikan motivasi dan perubahan perilaku individu.

Dalam kehidupan sehari-hari pasien GGK sangat memiliki ketergantungan terhadap terapi hemodialisa yang bertujuan untuk memperpanjang umur dan meningkatkan kualitas hidup pasien GGK dan keluarga pasien terlibat langsung alam pelaksanaan terpi hemodialisa sehingga muncul beberapa masalah yang dapat menyebabkan penurunan motivasi keluarga pasien GGK dalam merawat pasien yang melakukan terapi hemodialisa. Tujuan penelitian ini untuk mengetahui pengaruh supportive educative group therapy terhadap peningkatan motivasi dan penerimaan keluarga dalam merawat pasien GGK dengan hemodialisa (Appelbaum, A.H, 2005).

\section{METODE}

Penelitian ini menggunakan desain PreEksperimen Design dengan menggunakan pendekatan penelitian one-group pre-post test design. Lokasi penelitian adalah ruang Hemodialisa Rumah Sakit Bhayangkara Kediri dalam waktu 1 bulan. Besar sampel 30 orang responden. Pengambilan sampel menggunakan teknik accidental sampling. Kriteria inklusi dalam penelitian ini adalah keluarga Pasien GGK yang bersedia menjadi responden dalam penelitian ini dan mengalami penurunan motivasi yang keluarganya sudah menjalani hemodialisa lebih dari 1 tahun. Instrumen penelitian ini berupa kuesioner motivasi dan penerimaan yang sudah melalui uji validitas dan reabilitas.

Penelitian ini yaitu memberikan kuesioner motivasi dan penerimaan keluarga dalam merawat pasien GGK (pre-test). Selanjutnya keluarga yang memiliki motivasi dan penerimaan dalam kategori rendah dan sedang akan diberikan supportive educative group therapy selama 45 menit setiap sesinya, terdiri dari 4 sesi dan dilakukan dalam 2 kali pertemuan dalam 1 minggu. Setelah diberikan supportive group therapy responden akan diberikan kuesioner motivasi keluarga dalam merawat pasien GGK.

\section{HASIL}

Tabel 1. Distribusi Frekuensi Responden Berdasarkan Umur, Jenis Kelamin, Pekerjaan dan Lama Keluarga Merawat Pasien Menjalani Terapi Hemodialisa

\begin{tabular}{crr}
\hline $\begin{array}{c}\text { Karakteristik } \\
\text { responden }\end{array}$ & f & \% \\
\hline Usia & 9 & 30 \\
$18-40$ tahun & 15 & 50 \\
$41-60$ tahun & 6 & 20 \\
$>60$ tahun & & \\
Jenis kelamin & 21 & 70 \\
Laki laki & 9 & 30 \\
Perempuan & & \\
& & \\
Pekerjaan & 6 & 20 \\
Petani & 6 & 20 \\
Buruh & 6 & 20 \\
PNS & 12 & 40 \\
Wiraswasta & & \\
Lama keluarga & & \\
merawat pasien & & \\
menjalani hemodialisa & 6 & 20 \\
1 tahun & 6 & 60 \\
2 tahun & 20 \\
3 tahun &
\end{tabular}

Berdasarkan tabel 1 menunjukkan bahwa separuh responden $(50 \%)$ berjumlah 15 orang dengan usia 41-60 tahun, sebagian besar responden $(70 \%)$ berjumlah 21 orang dengan jenis kelamin laki-laki, mayoritas responden (70\%) berjumlah 21 orang dengan riwayat pendidikan SMA/ Sederajat, Hampir setengah 
responden (40\%) berjumlah 12 orang bekerja sebagai wiraswasta dan sebagian besar responden $(60 \%)$ berjumlah 18 orang memiliki anggota keluarga yang menjalani terapi hemodialisa selama 2 tahun.

Tabel 2. Distribusi Karakteristik Motivasi Keluarga dalam Merawat Pasien Gagal Ginjal Kronik yang Menjalani Terapi Hemodialisa Sebelum Dilakukan Supportive Educative Group Therapy

\begin{tabular}{lrr}
\hline Karakteristik & \multicolumn{2}{c}{ Pretest } \\
\cline { 2 - 3 } Motivasi Keluarga & \multicolumn{2}{c}{ f } \\
\hline Tinggi & 0 & 0 \\
Sedang & 15 & 50 \\
Rendah & 15 & 50 \\
\hline Total & 30 & 100 \\
\hline
\end{tabular}

Berdasarkan tabel 2 diketahui 50\% responden berjumlah 15 orang memiliki motivasi dengan kategori rendah dan 50\% responden berjumlah 15 orang memiliki motivasi dengan kategori sedang.

Tabel 3. Distribusi Karakteristik Motivasi Keluarga dalam Merawat Pasien Gagal Ginjal Kronik yang Menjalani Terapi Hemodialisa Sesudah Dilakukan Supportive Educative Group Therapy

\begin{tabular}{lrr}
\hline Karakteristik & \multicolumn{2}{c}{ Pretest } \\
\cline { 2 - 3 } Motivasi Keluarga & \multicolumn{1}{c}{ f } & \multicolumn{1}{c}{$\%$} \\
\hline Tinggi & 24 & 80 \\
Sedang & 6 & 30 \\
Rendah & 0 & 0 \\
\hline Total & 30 & 100 \\
\hline
\end{tabular}

Berdasarkan tabel 3 setelah diberikan supportive educative group therapy selama 4 sesi/pertemuan hampir seluruh responden (80\%) memiliki motivasi dengan kategori tinggi.

Tabel 4. Distribusi Karakteristik Motivasi Keluarga dalam Merawat Pasien Gagal Ginjal Kronik yang Menjalani Terapi Hemodialisa Sebelum dan Sesudah Dilakukan Supportive Educative Group Therapy

\begin{tabular}{lrrrrr}
\hline \multirow{2}{*}{ Tingkat } & \multicolumn{2}{c}{ Pre-Test } & \multicolumn{2}{c}{ Post-Test } \\
\cline { 2 - 6 } \multicolumn{1}{c}{ Motivasi } & f & \% & \multicolumn{1}{c}{ f } & \% \\
\hline Tinggi & 0 & 0 & 8 & 80 \\
\hline Sedang & 5 & 50 & 2 & 20 \\
\hline Rendah & 5 & 50 & 0 & 0 \\
\hline Total & 10 & 100 & 10 & 100 \\
\hline Uji & \multicolumn{5}{c}{ p-value $0,005(\alpha=0,05)$} \\
Wilcoxon & \multicolumn{5}{c}{} \\
\hline
\end{tabular}

Berdasarkan tabel 4 diketahui sebelum pemberian supportive educative group therapy, separuh responden $(50 \%)$ memiliki motivasi dalam kategorimotivasi rendah, dan separuh rerponden memiliki motivasi dalam kategori sedang. Sedangkan setelah diberikan supportive educative group therapy selama 4 sesi/pertemuan hampir seluruh responden $(80 \%)$ memiliki motivasi dalam kategori motivasi tinggi. Dari hasil penelitian menunjukan bahwa $\rho$-value 0,005 , berarti terdapat pengaruh supportive educative group therapy terhadap motivasi keluarga dalam merawat pasien gagal ginjal kronik yang mejalani terapi hemodialisa di RS Bhayangkara Kediri.

Tabel 5. Penerimaan Keluarga Sebelum Diberikan Intervensi Supportive Educative Group Therapy

\begin{tabular}{lrr}
\hline \multicolumn{1}{c}{ Kategori } & \multicolumn{2}{c}{ Pre-test } \\
\cline { 2 - 3 } Penerimaan & f & \% \\
\hline Rendah & 24 & 80 \\
Tinggi & 6 & 20 \\
\hline Jumlah & 30 & 100 \\
\hline
\end{tabular}

Dari tabel di atas menunjukkan bahwa mayoritas penerimaan keluarga sebelum dilakukan intervensi dalam kategori rendah sebanyak $80 \%$.

Tabel 6. Penerimaan Keluarga dalam Merawat Penderita GGK dengan Hemodialisa setelah Diberikan Supportive Educative Group Therapy

\begin{tabular}{lrr}
\hline \multirow{2}{*}{ Kategori } & \multicolumn{2}{c}{ Post test } \\
\cline { 2 - 3 } Penerimaan & \multicolumn{1}{c}{ f } & \multicolumn{1}{c}{$\%$} \\
\hline Rendah & 2 & 7 \\
Tinggi & 28 & 93 \\
\hline Jumlah & 30 & 100 \\
\hline
\end{tabular}

Dari tabel 6 menunjukkan bahwa hampir seluruh penerimaan keluarga dalam kategori tinggi (93\%).

Tabel 7. Hasil Analisis Pengaruh Supportive Educative Group Therapy dan Penerimaan Keluarga

\begin{tabular}{lc}
\hline \multicolumn{1}{c}{ Hasil Uji Statistik } & p-value \\
\hline Hasil Uji Satatistik & \\
dengan Wilcoxon Sign & 0,001 \\
Rank Test & \\
\hline
\end{tabular}

Berdasarkan tabel 7 di atas maka dapat disimpulkan bahwa dari perhitungan data hasil uji Wilcoxon Sign Rank Test diperoleh hasil sig $\rho$-value 0,001 dengan tingkat sig $\alpha 0,05$ berarti ada pengaruh supportive educative group therapy 
terhadap penerimaan keluarga dalam merawat penderita GGK dengan hemodialisa.

\section{PEMBAHASAN}

\section{Identifikasi Motivasi Keluarga dalam Merawat Pasien Gagal Ginjal Kronik yang Menjalani Terapi Hemodialisa Sebelum Dilakukan Supportive Educative Group Therapy}

Berdasarkan tabel 1 menunjukkan bahwa separuh responden $(50 \%)$ berjumlah 15 orang dengan usia 41-60 tahun. Motivasi keluarga sebelum diberikan intervensi 50\% responden berjumlah 15 orang memiliki motivasi dengan kategori rendah dan 50\% responden berjumlah 15 orang memiliki motivasi dengan kategori sedang. Keluarga adalah dua atau lebih individu yang tergabung karena ikatan tertentu untuk saling membagi pengalaman dan melakukan pendekatan emosional. Fungsi kesehatan yang dimaksud adalah keluarga memiliki tugas kesehatan keluarga seperti keluarga mengenal masalah kesehatan, keluarga mampu mengambil keputusan yang tepat untuk memiliki masalah kesehatan, keluarga mampu merawat anggota keluarga yang mengalami masalah kesehatan, memodifikasi lingkungan menciptakan dan mempertahankan suasana rumah yang sehat, keluarga mampu memanfaatkan fasilitas pelayanan keluarga,

Faktor yang mempengaruhi motivasi keluarga dalam memberikan dukungan terhadap klien gangguan jiwa, faktor yang mempengaruhi motivasi keluarga adalah nilai/keyakinan, emosi, dan persepsi (Zaidin, 2009). Berbeda dengan hasil penelitian ini, motivasi keluarga dipengaruhi oleh proses perawatan pasien gagal ginjal kronik tersebut. Karena keluarga harus membantu pasien dalam proses keperawatan yang dijalani pasien gagal ginjal kronik dan lama pasien dalam menjalani terapi hemodialisa. Sebagian besar responden memiliki anggota keluarga yang telah menjalani terapi hemodialisa selama 2 tahun.

\section{Identifikasi Motivasi Keluarga dalam Merawat Pasien Gagal Ginjal Kronik yang Menjalani Terapi Hemodialisa Sesudah Dilakukan Supportive Educative Group Therapy}

Setelah diberikan supportive educative group therapy selama 4 sesi/ pertemuan hampir seluruh responden $(80 \%)$ memiliki motivasi dengan kategori tinggi. Motivasi sesudah dilakukan supportive group therapy selama 4 sesi/pertemuan sebagian besar mengalami peningkatan menjadi motivasi baik.Perilaku dukungan sosial terdiri dari informasi dan nasehat verbal dan non verbal, bantuan nyata, atau tindakan yang diberikan oleh keakraban sosial atau didapat karena kehadiran mereka dan mempunyai manfaat emosional atau efek perilaku bagi pihak penerima (Stuart,G.W \& Laraia, M.T , 2005). Dukungan sosial sangat mempengaruhi dalam memotivasi keluarga dalam merawat pasien gagal ginjal kronik dalam menjalani terapi hemodialisa, meliputi dukungan emosional, dukungan penghargaan, dukungan instrumental, dukungan informasi dan dukungan jaringan sosial (Chien, 2006). Penyakit Gagal ginjal merupakan penyakit kronis yang memerlukan dukungan positif dari keluarga seperti penyakit kronis lainnya seperti Diabetes Mellitus. Individu yang menderita penyakit kronis dan keluarganya harus mampu menyelesaikan barrier/ hambatan agar motivasi dalam melakukan pengobatan dapat meningkat (Nuari, NA, 2015).

Pemberian supportive educative group therapy pada keluarga dengan klien GGK yang menjalani hemodialisa sangat diperlukan guna membantu keluarga untuk menyelesaikan masalah. Masalah dalam keluarga tersebut diantaranya beban ekonomi karena tindakan hemodialisa membutuhkan biaya yang tinggi dan rutin secara terus menerus. Beban secara psikologis yaitu keluarga harus mau mengantar anggota keluarga ke tempat pelayanan kesehatan dengan menunggu terapi hemodialisa dapat mengakibatkan kejenuhan. Waktu yang dibutuhkan antara 4-5 jam juga dapat digunakan oleh keluarga untuk hal yang lain. Dampak yang terjadi bila tidak diberikan terapi suportif pada keluarga adalah terganggunya struktur dan peran keluarga seperti terjadinya ketidakharmonisan, merasa diabaikan dan merasa tidak perlu diperhatikan serta tidak mampu memenuhi kebutuhan dalam keluarga. Pada klien juga akan mengalami beban psikologis yang berarti diantaranya klien merasa menjadi beban dalam keluarga. Pemberian terapi suportif akan memberikan keuntungan pada keluarga seperti keluarga dapat mengekpresikan masalah yang dihadapi, keluarga tidak merasa bahwa hanya sendirian saja yang mengalami beban, keluarga mendapatkan support sistem dari keluarga lain. Setiap anggota keluarga lain akan saling mendukung dan saling memahami permasalahan dalam keluarganya. Efektifitas strategi koping bergantung pada kebutuhan individu, usia individu dan latar belakang budaya 
mempengaruhi kebutuhan tersebut. Karena alasan tersebut, tidak ada strategi koping tunggal bekerja pada setiap orang.

Sejalan dengan penelitian sebelumnya peneliti menggunakan terapi suportif tetapi peneliti menggunakan bagian dari terapi suportif yaitu supportive group therapy dengan penggunaan terapi ini didapatkan hasil bahwa supportive educative group therapy berpengaruh pada motivasi keluarga dalam merawat pasien gagal ginjal kronik yang menjalani terapi hemodialisa. Motivasi terbentuk karena adanya dukungan informasi yang positif sehingga individu mampu berperilaku yang baik (Afrian dkk, 2016).

Analisis Pengaruh Supportive Educative Group Therapy terhadap Motivasi Keluarga dalam Merawat Pasien Gagal Ginjal Kronik yang Menjalani Terapi Hemodialisa

Berdasarkan hasil penelitian ini diketahui pre-test supportive group therapy terhadap motivasi keluarga dalam merawat pasien GGK yang menjalani terapi hemodialisa. Separuh responden $(50 \%)$ memiliki motivasi dalam kategori rendah, sedangkan setelah perlakuan (post-test) dilakukan supportive group therapy selama 4 sesi/pertemuan sebagian besar $(80 \%)$ mengalami peningkatan motivasi menjadi dalam kategori motivasi tinggi dengan rincian sebanyak 5 responden $(50 \%)$ yang awalnya memiliki motivasi rendah setelah diberikan supportive group therapy mengalami peningkatan motivasi sebanyak 3 responden $(30 \%)$ memiliki motivasi tinggi dan 2 responden $(20 \%)$ memiliki motivasi sedang dan sebanyak 5 responden (50\%) yang awalnya memiliki motivasi dalam kategori cukup seluruhnya mengalami peningkatan motivasi menjadi motivasi dalam kategori tinggi. Diperoleh hasil sig $\rho$-value $=0,005$ menunjukan bahwa H1 diterima, berarti terdapat pengaruh supportive group therapy terhadap motivasi keluarga dalam merawat pasien gagal ginjal kronik yang mejalani terapi hemodialisa di RS Bhayangkara Kediri.

Supportive Educative Group Therapy adalah persepsi individu mengenai adanya ketersediaan orang-orang di sekitar individu yang dapat memberikan cinta, pertolongan, perhatian serta penghargaan baik dalam bentuk emosi dan tingkah laku. Sehingga, individu yang bersangkutan mendapatkan kenyamanan secara fisik dan psikologis. Didalam supportive educative group therapy terdapat 4 sesi yaitu pertama Mengidentifikasi kemampuan keluarga dan sumber pendukung yang ada, kedua menggunakan sistem pendukung dalam keluarga, monitor dan Hambatannya, ketiga menggunakan sistem pendukung di luar keluarga, memonitor dan hambatannya, keempat mengevaluasi hasil dari hambatan pengunaan sumber. Dengan terapi ini akan terjalin komunikasi antar keluarga, sehingga akan muncul solusi solusi tentang permasalahan yang dihadapi oleh keluarga sehingga mekanisme koping keluarga meningkat dan berpengaruh pada peningkatan motivasi keluarga dalam merawat pasien gagal ginjal kronik yang menjalani terapi hemodialisa.

Pada dasarnya lingkungan sekitar terutama keluarga yang bersifat mendukung dalam kehidupan sehari-hari dapat menimbulkan dua hal: 1) Meningkatkan motivasi individu 2) Meningkatkan perasaan diterima (sense of acceptance). Inti dari hubungan yang sifatnya mendukung adalah komunikasi antara acceptance dan cinta. Ketika lingkungan di sekitar individu sangat mendukung individu dalam waktu tertentu, maka motivasi serta rasa keberhargaan diri (self worth) akan menjadi bagian yang stabil dalam kepribadian individu. Hal ini berarti individu akan terbebas dari kekecewaan yang ada di dalam diri. Sehingga individu dapat mengeksplorasi tujuan yang baru serta dapat berinteraksi secara bebas dan terbuka dengan orang lain di sekitarnya. Individu juga akan mampu untuk berhadapan dengan segala tantangan yang ada dalam kesehariannya. Hal-hal inilah yang pada akhirnya memberikan kesempatan bagi individu untuk mengembangkan efikasi diri dan rasa keberhargaan diri yang lebih baik. Seseorang yang mempunyai self efikasi mempunyai resiliensi dalam mengatasi masalahnya (Nuari, NA, 2015).

Dalam penelitian ini 1 responden (10\%) memiliki progress peningkatan motivasi yang signifikan responden tersebut berumur 61 tahun berjenis kelamin laki-laki memiliki riwayat pendidikan SMA/sederajat memiliki pekerjaan sebagai seorang wiraswasta dan anggota keluarganya telah 2 tahun menjalani terapi hemodialisa awalnya skor yang diperoleh adalah 29 yaitu kategori motivasi rendah dan mengalami peningkatan menjadi motivasi tinggi dengan skor 57. Motivasi juga dipengaruhi kemampuan intelektual individu. Individu yang mempunyai latar belakang pendidikan baik akan lebih mudah menerima proses perubahan pada dirinya, yang terkait masukan dari eksternal seperti supportive educative dalam teman sejawat sehingga akan meningkatkan pemberdayaan dirinya dalam melakukan sesuatu (Nuari, NA, 2016).Sesuai dengan hasil penelitian yang telah dilakukan menunjukkan bahwa terdapat perbedaan yang signifikan antara motivasi responden sebelum 
dilakukan supportive group

dibandingkan dengan sesudahnya.

\section{Identifikasi Penerimaan Keluarga Sebelum Diberikan Supportive Educative Group Therapy}

Mayoritas penerimaan keluarga sebelum dilakukan intervensi dalam kategori rendah sebanyak $80 \%$. Penerimaan diri merupakan peran penting dan berpengaruh besar terhadap sikap dan perilaku seseorang. Penerimaan diri yang rendah merupakan masalah bagi banyak orang dan di ekspresikan melalui tingkat kecemasan yang sedang maupun berat. Penerimaan diri yang baik apabila seseorang mempunyai keyakinan akan kemampuannya untuk menghadapi kehidupannya, kemudian dapat menganggap dirinya berharga sebagai seseorang manusia yang sederajat dengan orang lain, memiliki keberanian untuk memikul tanggung jawab terhadap perilakunya, serta dapat menerima pujian dan celaan secara obyektif, dan tidak menyalahkan dirinya akan keterbatasan yang dimilikinya ataupun mengingkari kelebihannya.

\section{Penerimaan Keluarga Setelah Dilakukan Supportive Educative Group Therapy}

Berdasarkan hasil perhitungan frekuensi yang terlihat dalam tabel 6 menunjukkan bahwa peningkatan penerimaan keluarga setelah dilakukan supportive educative group therapy, hampir seluruh responden (93\%) mengalami penerimaan yang tinggi, jadi jika dilihat dari hasil diatas terjadi perubahan yang signifikan hampir seluruh responden mengalami peningkatan penerimaan. Adapun faktor-faktor yang mempengaruhi penerimaan keluarga antara lain pemahaman terhadap kondisi anggota keluarga yang sakit, harapan yang realistis, tidak adanya hambatan-hambatan dari lingkungan, tingkah laku sosial yang mendukung (dukungan sosial), tidak adanya tekanan emosi, keberhasilan, identifikasi bagi orang yang mempunyai penyesuaian diri yang baik.

Penerimaan keluarga yang rendah merupakan masalah bagi banyak orang dan di ekspresikan dengan tingkat kecemasan yang sedang maupun berat. Dengan keadaan penerimaan yang rendah seperti itu diharapkan supportive educative group therapy dapat membantu guna tercapainya tujuan. Supportive educative group therapy adalah dukungan yang diberikan dari sekelompok orang yang merasa memiliki beberapa kesamaan baik dari segi usia, pola pikir, minat, atau hal yang lain kepada orang yang mengaku atau mempunyai hal serupa. Alasan peneliti menerapkan intervensi ini sebagai salah atu upaya peningkatan penerimaan keluarga dilihat dari salah satu fungsi supportive educative group therapy adalah berhubungan dengan peningkatan penerimaan keluarga. Dalam kehidupannya, individu menjumpai ancamanancaman terhadap kemampuannya, daya tarik fisiknya, atau kepercayaan dirinya. Kelompok bisa menjadi media katarsis, tempat anggota kelompok mencurahkan masalah yang dirasakan sehingga dengan demikian individu diasumsikan tentu akan memilih orang yang benar-benar dianggap dekat.

Peningkatan penerimaan keluarga dengan dukungan kelompok ini belum bisa dipahami sepenuhnya oleh para ahli, namun diyakini bahwa dengan kesediaan mendengarkan, kelompok memberikan dukungan psikologis kepada anggota-anggotanya sebagai seorang yang berkemampuan dan layak untuk dihargai. Bahwa peningkatan penerimaan keluarga bisa dlakukan dengan menggunakan supportive educative group therapy. Berdasarkan hasil penelitian responden menyatakan merasa nyaman dengan keadaan anggota keluarga yang sakit dan mampu menerima keadaan yang anggota keluarga mereka alami, responden mampu merawat anggota keluarga yang sakit yang membutuhkan bantuan.

Penerimaan keluarga juga dipengaruhi oleh beberapa faktor antara lain usia, agama, pekerjaan, pendidikan terakhir responden. Usia berpengaruh karena semakin tua keluarga akan semakin dapat menerima bahwa semua keadaan ini adalah masalah yang harus dihadapi dengan ikhlas dan lapang, dalam hal ini agama juga berpengaruh dikarenakan semakin tinggi nilai keimanan keluarga akan semakin tinggi pula pemahaman tentang masalah yang dihadapi oleh keluarga dengan anggota keluarga yang menderita GGK dengan hemodialisa, pekerjaan juga mempengaruhi dikarenakan apabila keluarga yang bekerja akan mengurangi tingkat kebersamaan dengan anggota keluarga yang sakit sehingga sulit memahami apa yang penderita inginkan dan butuhkan, pendidikan terakhir responden akan mempengaruhi tentang tingkat pemahaman tentang terapi yang diperlukan oleh penderita. Oleh sebab itu penerimaan keluarga berbeda antara yang satu anggota keluarga dengan yang lainnya. Setiap individu mempunyai kemampuan intelektual yang berbeda-beda yang berpengaruh terhadap penerimaan individu sehingga mampu melakukan perilaku yang supportive (Nuari, NA\& Kartikasari, M, 2015). 
Analisis Pengaruh Supportive Educative Group Therapy terhadap Penerimaan Keluarga

Untuk mengetahui hasil dari penelitian tersebut peneliti dalam pengolahan data menggunakan uji wilcoxon yang digunakan untuk membandingkan antar pre test dan post test. Menurut analisis, ada pengaruh pemberian Supportive educative group therapy sebagai salah satu upaya untuk peningkatan penerimaan keluarga pada anggota keluarga dengan GGK yang menjalani hemodialisa. Hal ini dibuktikan dengan nilai $p$-value $=0,001$ yang menyatakan ada pengaruh supportive educative group therapy terhadap penerimaan keluarga dengan penderita GGK dengan hemodialisa.

Metode supportive educative group therapy dapat mempengaruhi penerimaan keluarga dikarenakan dalam kegiatan supportive educative group therapy dibebaskan untuk memberikan atau menceritakan semua masalah yang dihadapi yang berhubungan dengan anggota keluarga yang sakit, keluarga juga dapat bertukar pengalaman tentang cara atau metode belajar yang digunakan oleh anggota lain yang sangat efektif untuk mengatasi masalah yang dihadapi, serta didalam kegiatan supportive educative group therapy ini semua anggota akan menjadi lebih empati terhadap anggota lain. Dukungan dari anggota kelompok inilah yang menjadikan intervensi ini sangat baik untuk meningkatkan penerimaan keluarga. Dukungan yang diberikan anggota kelompok adalah dukungan emosional yang mencakup ungkapan empati dari anggota kelompok, peduli terhadap masalah yang dihadapi anggota kelompok, serta perhatian yang diberikan oleh anggota lain.

Supportive educative group therapy ini memiliki beberapa tahapan antara lain cheking in, presentasi masalah, klasifikasi masalah, berbagi usulan, perencanaan tindakan dan yang tekhir checking out). Di sesi pertama cheking in dilakukan oleh semua anggota untuk menyatakan bahwa dirinya akan mengikuti kelompok ini. Kemudian presentasi masalah, semua anggota berhak mengutarakan masalah yang dialami dan masalah yang disampaikan dapat dijadikan bahan sebagai materi pertemuan. Sesi klasifikasi masalah yang telah disampaikan oleh anggota pada sesi sebelumnya dibahas bersama-sama untuk dicari jalan keluarnya. Sesi berbagi usulan yaitu anggota lain yang memiliki masalah yang sama dan telah dapat menyelesaikannya dapat berbagi pengalaman dan berbagi cara penyelesaian yang baik. Untuk sesi perencanaan tindakan semua anggota merencanakan suatu strategi tindakan yang akan dilakukan untuk membantu anggota kelompok. Pada sesi terakhir adalah Cheking Out yaitu di sesi ini kelompok melakukan peninjauan ulang atas apa yang telah dibahas dan kelompok menentukan tema yang akan dibahas pada pertemuan berikutnya (Training in Human Right and Citizenship Education Council of Europe).

Tentang penerimaan diri ada pendapat bahwa penerimaan yang baik apabila memiliki penghargaan yang realistis terhadap kelebihankelebihan dirinya, memiliki keyakinan akan standar-standar dan prinsip-prinsip dirinya tanpa harus diperbudak oleh opini individu-individu lain, memiliki kemampuan untuk memandang dirinya secara realistis tanpa harus menjadi malu akan keadaannya. Mengenali kelebihankelebihan dirinya dan bebas memanfaatkan, mengenali kelemahan-kelemahan dirinya tanpa harus menyalahkan dirinya, memiliki spontanitas dan rasa tanggung jawab dalam diri, menerima potensi dirinya tanpa menyalahkan dirinya atas kondisi-kondisi yang berada diluar kontrol mereka, tidak melihat diri mereka sebagai individu yang harus dikuasai rasa marah atau takut atau menjadi tidak berarti karena keinginankeinginan tetapi dirinya bebas dari ketakutan untuk berbuat kesalahan, merasa memiliki hak untuk memiliki ide-ide dan keinginan-keinginan serta harapan-harapan tertentu, serta tidak merasa iri akan kepuasan-kepuasan yang belum diraihnya.

Intervensi ini dapat meningkatkan penerimaan keluarga dikarenakan didalam semua sesi yang ada semua anggota akan mendapatkan dukungan sosial, dengan dukungan sosial kelompok akan membuat anggota merasa dipahami, diterima keberadaannya dan dengan semua keadaanya. Semua anggota juga dapat mendapat pengalaman-pengalaman baru tentang cara atau terapi yang sangat tepat untuk mengadapi semua masalah yang dihadapi dalam merawat keluarga yang sakit. Didalam supportive eduvcatiuve group therapy anggota juga mendapatkan hubungan sosial yang baik yang memberikan kesempatan bagi anggota untuk menikmati berbagai kebersamaan, minat dan sikap mendukung yang diberikan dalam kelompok. Hal inilah yang sering berkembang menjadi rasa persahabatan serta senasip dan keluarga merasa tidak sendiri karena dalam kelompok semua anggota memberikan dukungan sehingga keluarga memiliki penerimaan diri yang positif. 


\section{SIMPULAN}

Dari hasil penelitian didapatkan bahwa memiliki motivasi dalam kategori rendah, sedang dan penerimaan keluarga dalam kategori rendah. Setelah diberikan Supportive Educative Group Therapymemiliki motivasi dalam kategori tinggi dan penerimaan keluarga dalam kategori tinggi.

Supportive Educative Group Therapy mempunyai pengaruh pada motivasi dan Separuh responden sebelum diberikan intervensi

penerimaan keluarga dalam merawat pasien gagal ginjal kronik yang menjalani terapi hemodialisa.

\section{SARAN}

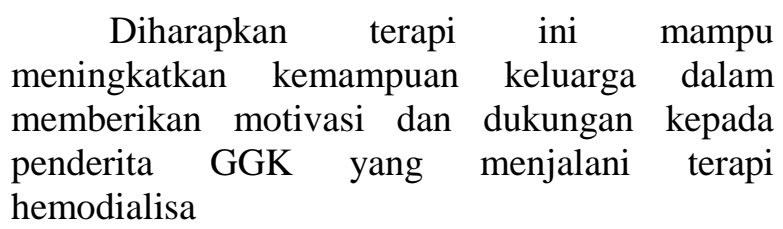

Nuari, NA. 2015. Model Peningkatan Resiliensi Anak Usia Sekolah Pasca Letusan Gunung Kelud Kediri Berbasis Disaster Nursing Competency. Jurnal SAINMED Kopertis VII Jawa Timur.

Nuari, N. A. 2016. Pengembangan Model Peningkatan Pemberdayaan Diri dan Kualitas Hidup Pasien Diabetes Mellitus Tipe 2. Jurnal Ners Lentera, 4(2), 152165.http://journal.wima.ac.id/index.php/N ERS/article/view/878

Appelbaum, A.H. 2005. Supportive therapy 4. http:www.focuspsychiatryonline.org/egi, (Diakses pada 20 oktober 2017).

Chien, W. T., Chan, S. W., \& Thompson, D. R. 2006. Effects of a mutual support group for families of Chinese people with schizophrenia: 18-month follow-up. The British journal of psychiatry, 189(1), 4149.

Badan Penelitian dan Pengembangan Kesehatan Depkes RI. 2013. Riset Kesehatan Dasar (Riskesdas). Jakarta.

Nuari, N. A. 2015. Analisis Korelasi Personal Factor, Perceived Benefit Dan Perceived Barrier Dengan Pemberdayaan Diri Pasien Diabetes Mellitus Tipe II Berbasis Teori Health Promotion Model. Gaster Jurnal Ilmu Kesehatan, 11(2), 37-48. http://www.jurnal.stikesaisyiyah.ac.id/index.php/gaster/article/vie $\mathrm{w} / 76 / 71$

Nuari, N. A., \& Kartikasari, M. 2015. Peningkatan Self Empowerment dan Kualitas Hidup Pasien Diabetes Mellitus Tipe II Dengan Pendekatan DEE Berbasis Health Promotion Model. Jurnal Ners Unair. http://e-journal. unair. ac. id/index. php/JNERS/article/view/14.
Nuari, Nian Afrian \& Widayati, Dhina. 2017. Gangguan Pada Sistem Perkemihan Dan Penatalaksanaan Keperawatan. Yogyakarta: Penerbit Deepublish.

Nuari, N. A. 2017. Self Instructional Training Methods to Reduce Blood Glucose Levels Type 2 Diabetes Mellitus. Jurnal Ners dan Kebidanan, 4(1), 6-11. http://jnk.phb.ac.id/index.php/jnk/article/vi ew/0157.

Smeltzer. 2008. Buku Ajar Keperawatan Medical Bedah. Jakarta: EGC.

Stuart, G.W \& Laraia, M.T 2005. Principles and Practice of Psychiatric Nursing. (8th. ed). St Louis: Mosby.

Widayati, Dhina \& Lestari, N. 2015. Peningkatan Kualitas Hidup Pada Penderita Gagal Ginjal Kronik Yang Menjalani Terapi Hemodialisa Melalui Psychological Intervention Di Unit Hemodialisa RSUD Gambiran Kediri. Jurnal Ilmu Kesehatan, 3, No 2, 6-11.

Zaidin. 2009. Pengantar Keperawatan Keluarga. Jakarta: EGC. 